\title{
Persepsi Mahasiswa Sosiologi FIS UNP Tentang Mata Kuliah Micro Teaching dan Pelaksanaan Praktek Lapangan Kependidikan (PLK)
}

\author{
Fiona Oktafia ${ }^{1}$, Desri Nora $A N^{2}$ \\ ${ }^{1,2}$ Universitas Negeri Padang \\ Email: fionaoktafia17@gmail.com, desrinora@ymail.com
}

\begin{abstract}
Abstrak
Penelitian ini dilatar belakangi oleh ketertarikan peneliti tentang banyak nya mahasiswa Pendidikan Sosiologi yang belum menguasai keterampilan dasar mengajar. Dalam micro teaching mahasiswa diajarkan keterampilan dasar mengajar. Sedangkan kenyataannya yang terjadi pada mahasiswa Pendidikan Sosiologi FIS UNP dalam mata kuliah micro teaching di lapangan banyak belum menguasai keterampilan dasar mengajar serta materi disampaikan belum maksimal, ada juga gugup dalam kelas. Tujuan dari penelitian ini adalah untuk mengetahui apakah mata kuliah micro teaching membantu mahasiswa Pendidikan Sosiologi FIS UNP dalam pelaksanaan praktek lapangan kependidikan (plk). Penelitian ini menggunakan pendekatan kualitatif dengan tipe studi kasus. Penelitian menggunakan teori Talcott Parson yaitu teori Struktural Fungsional dengan Skema AGIL. Teknik pemilihan informan adalah purposive sampling, dengan jumlah informan 10 orang. Penelitian ini menemukan bahwa mahasiswa Pendidikan Sosiologi ketika pelaksanaan praktek lapangan kependidikan memakai langkah-langkah micro teaching dan menguasai keterampilan dasar mengajar yang diajarkan dosen dapat membantu mahasiswa Pendidikan Sosiologi dalam pelaksanaan praktek lapangan kependidikan.
\end{abstract}

Kata kunci: Micro Teaching, PLK, Mahasiswa

\section{Abstract}

This research is motivated byresearcher's interest in many sociology students who had not yet mastered basic teaching skills. In micro teaching students are taught basic teaching skills. Whereas, what is said in the case of sociology students UNP in the micro teaching course in the field, is that many have not mastered basic teaching skills and presented material, yet there is nervzation in the classroom. The purpose of this study was to find out wheter the micro teaching course was assisting sociology students at nop's university in the performance of educational field practice (PLK). the study uses a qualitative approach with the type of case study. Research uses the parson's talcott theory, a functional structural theory with AGIL schemes. The informant selection technique is an impressive sampling, with the number of informants 10 people. The study found that sociology students when performing educational field practices took the steps of micro reaching and mastered basic teaching skills that teachers taught could assist sociology students in performing educational field practices.

Keywords: Micro Teaching, PLK, College Student

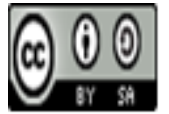

\begin{tabular}{|l|l|l|l} 
Received: August 5, 2020 & Revised: August 18, 2020 & Acepted: August 19, 2020
\end{tabular} 


\section{Pendahuluan}

Pendidikan merupakan suatu hal yang sangat dibutuhkan bagi setiap individu. Manusia sebagai individu memerlukan pendidikan agar mampu berkembang seiring dengan perkembangan zaman. Pendidikan sangat penting bagi kemajuan suatu bangsa. Pada zaman sekarang guru di Indonesia masih ada yang tidak menguasai materi pelajaran yang akan di ajarkan (Ira Fitria, Syamwil, 2018). Calon pendidik harus dibekali dengan berbagai pengalaman baik teoritis maupun pengalaman praktis agar nanti di dalam kelas terbiasa menjadi seorang pendidik yang profesional (Wati, 2017). Demi menghasilkan calon guru yang berkompeten, maka di susun mata kuliah yang memberikan pengetahuan dan keahlian kepada mahasiswa calon guru tentang pembelajaran dan kegiatan kependidikan diantaranya dengan adanya mata kuliah micro teaching dan pelaksanaan praktek lapangan kependidikan (Vadelha \& Body, 2019).

Pembelajaran di sekolah merupakan proses komunikasi dua arah, mengajar dilakukan oleh guru, dan belajar dilakukan oleh siswa (Nur Azizah, 2019). Pengajaran adalah interaksi belajar dan mengajar (Nur Azizah, 2019). Dalam proses pembelajaran berlangsung saling mempengaruhi antara pendidik dan peserta didik. Proses pembelajaran berlangsung, didalamnya terdapat komponen yaitu tujuan mengajar, peserta didik yang belajar, pendidik yang mengajar, metode yang diajarkan, alat untuk membantu mengajar disekolah, penilaian dan situasi pembelajaran di sekolah (Nur Azizah, 2019).

Pendidik merupakan peranan penting dalam pendidikan dan pendidik juga merupakan penentu tingkat keberhasilan siswa. Dalam hal ini guru yang dapat membantu ketercapaian pembelajaran ialah seorang guru yang profesional dan berkualitas. Guru yang profesional merupakan guru yang memiliki kemampuan untuk melakukan tugas pendidikan dan pengajaran (Nur Azizah, 2019). Untuk menjadi calon guru sosiologi yang berkompeten sudah seharusnya mahasiswa Pendidikan Sosiologi harus memiliki kompetensi pedagogik (Satuik Rahayu, 2017). Latihan mengajar merupakan kegiatan belajar mengajar dalam kelas micro teaching untuk mengembangkan kemampuan keterampilan mahasiswa calon guru dalam melakukan kegiatan pembelajaran sebelum turun ke lapangan (Ardi, 2014). Sebelum melakukan kegiatan latihan mengajar, mahasiswa calon guru mendapatkan pedoman apa yang di pelajari di kelas micro teaching (Ardi, 2014). Dengan konteks sesungguhnya, mengajar mengandung banyak tindakan, baik dalam penyampaian materi pembelajaran, menggunakan metode pembelajaran di kelas, menggunakan media pembelajaran di kelas, membimbing siswa dalam belajar, memberikan motivasi kepada siswa, cara pengelolaan kelas, memberikan penilaian dan seterusnya (Ardi, 2014).

Melatih adalah suatu keterampilan yang sangat penting, terdiri dari keterampilan dasar mengajar yang penguasannya dapat dilatih. Untuk itu, keterampilan dasar mengajar dikelas yang kompleks, dapat dipilih menjadi keterampilan dasar mengajar yang sederhana, yang mudah dikontrol oleh calon pendidik (Ardi, 2014). Penguasaan mengajar dikelas dengan sendirinya membentuk kemampuan pendidik secara utuh (Ardi, 2014). Oleh sebab itu, ketekunan dalam berlatih, mengkaji kekurangan dan kelebihan dalam latihan dari dosen pembimbing mata kuliah micro teaching, keterampilan dasar mengajar dapat dilatihkan melalui pengajaran micro teaching (Ardi, 2014). Untuk menjadi guru yang profesional, mahasiswa calon guru diberi bekal pengetahuan seperti pemberian mata kuliah kependidikan yaitu perencanaan pembelajaran, media pembelajaran, strategi pembelajaran, dan masih banyak lagi yang lainnya. Semua pengetahuan diimplementasikan dalam kegiatan praktik berupa micro teaching dan praktek lapangan kependidikan (PLK) (Khuriyah, 2017).

Sebelum pelaksanaan Program Praktek Lapangan Kependidikan, mahasiswa telah melalui persiapan-persiapan teori maupun praktek agar mahasiswa tidak merasa kaku di hadapan siswa, karena sebelum terjun ke lapangan tempat praktek terlebih dahulu telah melakukan latihan pengajaran. Pengajaran micro teaching adalah salah satu bentuk contoh praktik kependidikan atau 
pelatihan mengajar bagi calon pendidik di kampus (Ardi, 2014). Jurusan Sosiologi, Fakultas Ilmu Sosial, Universitas Negeri Padang memiliki kewajiban menyiapkan dan melaksanakan pendidikan dan pelatihan setiap calon guru. Selama perkuliahan micro teaching Jurusan Sosiologi FIS UNP, tampak bahwa dalam mengikuti perkuliahan micro teaching, mahasiswa dituntut untuk menjadi guru dan harus menguasai keterampilan dasar mengajar, tetapi ada beberapa mahasiswa calon guru belum menguasai keterampilan dasar mengajar, masih gugup dalam kelas dan ada beberapa mahasiswa yang lancar mengikuti micro teaching di dalam kelas.

Kelulusan mata kuliah micro teaching ini merupakan salah satu syarat bagi mahasiswa calon guru untuk mengikuti Praktek Lapangan Kependidikan (PLK). bukan hanya sekedar menjadi syarat, namun melalui micro teaching inilah sebenarnya mahasiswa calon guru mempersiapkan diri dan mendapatkan pengalaman nyata dalam berlatih mengajar. Jika pelaksanaan pembelajaran micro teaching dapat berjalan dengan baik, mak akan memberikan banyak manfaat bagi calon guru. Pada saat Praktek Lapangan Kependidikan (PLK) mahasiswa calon guru harus menguasai keterampilan dasar mengajar, serta perangkat atau media yang dilakukan sudah disiapkan dan ketika tampil masih ada beberapa mahasiswa yang belum menguasai keterampilan dasar mengajar, ada masih gugup dan cemas ketika tampil di dalam kelas. Micro teaching dan Praktek Lapangan Kependidikan (PLK) sangat penting bagi calon guru di dalam micro teaching mahasiswa calon guru diajarkan keterampilan dasar mengajar supaya pada saat praktek lapangan kependidikan (plk) tidak kaku, tidak gugup dalam kelas dan terbiasa mengajar dikelas. Sedangkan kenyataannya yang terjadi pada mahasiswa Pendidikan Sosiologi belum menguasai keterampilan dasar mengajar pada micro teaching dan praktek lapangan kependidikan. Penelitian ini dianalisis menggunakan teori Struktural Fungsional oleh Talcott Parson dengan skema AGIL.

\section{Metode Penelitian}

Di dalam penelitian ini metode yang digunakan adalah pendekatan kualitatif (Nana Syaodih, 2013). Pendekatan kualitatif ialah suatu penelitian yang diacukan untuk menggambarkan dan mengkaji fenomena, peristiwa aktivitas sosial, sikap, kepercayaan, persepsi, pemikiran orang secara individual maupun kelompok. Tipe penelitian ini merupaka studi kasus. Studi kasus adalah tipe penelitian yang dapat memahami gambaran yang mendalam dan mendetail tentang suatu situasi atau objek (Yusuf, 2007). Penelitian ini dilakukan di Jurusan Sosiologi Fakultas Ilmu Sosial Universitas Negeri Padang. Alasan penelitian ini dilakukan di FIS UNP, karena peneliti memiliki pengalaman pada mata kuliah micro teaching dan di dalam praktek lapangan kependidikan. Teknik yang digunakan adalah teknik purposive sampling dengan informan 10 orang mahasiswa Pendidikan Sosiologi. Teknik pengumpulan data melalui observasi, wawancara dan dokumentasi. Peneliti melakukan wawancara kepada informan untuk mengetahui tentang persepsi Mahasiswa Sosiologi FIS UNP tentang mata kuliah micro teaching dan pelaksanaan praktek lapangan kependidikan (plk). dalam wawancara, peneliti mengumpulkan data yang digunakan untuk memperoleh informasi secara lisan melalui berbincang-bincang dan tatap muka dengan orang yang dapat memberikan informasi pada peneliti (Mardalis, 2010). Studi dokumentasi adalah perlengkap dari memakai metode observasi dan wawancara dalam penelitian (Sugiyono, 2017). Analisis data dilakukan dengan empat jalur kegiatan yang terjadi secara bersama, yaitu pengumpulan dataa, Reduksi Data, Penyajian Data, Verifikasi/menarik kesimpulan (Sugiyono, 2017).

\section{Hasil dan Pembahasan}

Sebelum melaksanakan Praktek Lapangan Kependidikan (PLK), mahasiswa Pendidikan Sosiologi harus mengikuti micro teaching. Di dalam mata kuliah micro teaching mahasiswa Pendidikan Sosiologi diajarkan keterampilan dasar mengajar. Pada saat tampil micro teaching tiaptiap mahasiswa diberikan kesempatan sebanyak 2 kali dan ada juga 3 kali dalam satu semester, yaitu pada semester 6 dengan berbobot 3 SKS. Waktu yang diberikan dosen untuk tampil praktik

Jurnal Sikola: Jurnal Kajian Pendidikan dan Pembelajaran Vol. 2, No. 1, Th. 2020 
mengajar sebanyak 15-20 menit. Setelah tampil mahasiswa calon guru diberikan kritik dan saran oleh mahasiswa (siswa) dan dosen supaya mahasiswa calon guru meperbaiki penampilannya pada pembelajaran micro teaching berikutnya. Pada mata kuliah micro teaching mahasiswa diharapkan dapat menguasai keterampilan dasar mengajar di dalam kelas. Dalam micro teaching terdapat keterampilan dasar mengajar yang harus dimiliki oleh calon pendidik dan selesai mata kuliah micro teaching mahasiswa calon guru harus memahami pedagogical content knowledge sebagai bekal bagi mahasiswa calon guru untuk persiapan menjadi guru yang profesional (Nur Azizah, 2019).

Dengan adanya mata kuliah micro teaching diharapkan mahasiswa yang akan menjadi calon pendidik supaya siap untuk mengajar dan menjadikan pembelajaran efektif pada pelaksanaan praktek lapangan kependidikan (Iyan Setiawan, 2018). Dalam praktek pembelajaran di dalam kelas upaya untuk mencapai keterampilan dasar mengajar yang baik bukanlah sesuatu yang mudah apalagi permasalahan pembelajaran kita dihadapkan dengan pola belajar yang mendorong kognitif. Tanpa disadari terdapat kelemahan pembelajaran kita terkait pada pola pikir kita sendiri. Hal ini disadari bahwa penguasaan kelas berjalan dengan lancar, pendidik harus memikili kemampuan keterampilan dasar mengajar supaya pembelajaran di kelas efektif (Iyan Setiawan, 2018).

Oleh karena itu, keterampilan dasar mengajar adalah hal yang sangat penting, karena keterampilan dasar mengajar adalah syarat supaya pendidik bisa menjalaani proses pembelajaran secara efektif. Menciptakan pembelajaran yang kreatif, dan menyenangkan, diperlukan keterampilan dasar mengajar (Iyan Setiawan, 2018). Kesiapan harus dicapai dalam proses perkembangan perorangan pada pertumbuhan mental, fisik, sosial dan emosional. Dengan mempunyai keterampilan dasar mengajar maka mahasiswa akan memiliki kesiapan menjadi seorang pendidik dalam mengajar dan akan menciptakan pembelajaran yang efektif (Iyan Setiawan, 2018).

Micro teaching atau pengajaran mikro. Pengajaran mikro meruapakan latihan tahap awal dalam pembentukan mengajar melalui keterampilan dasar mengajar. Pada dasarnya pengajaraan mikro adalah suatu metode pembelajaran dengan melatih keterampilan dasar mengajar dalam proses pebelajaran sehingga calon pendidik mampu menguasai keterampilan dasar mengajar di dalam kelas secara efektif (Untari et al, 2018).

Micro teaching sangat membantu mahasiswa calon guru dalam berkomunikasi dengan siswa yang sessungguhnya. Micro teaching adalah suatu media latihan bagi mahasiswa jurusan kependidikan sebelum praktek lapangan kependidikan di sekolah. micro teaching adalah sarana bagi mhasiswa calon guru melatih kemampuan mengajar di dalam kelas. Pembelajaraan micro teaching dapat diartikan sebagai latihan keterampilan keguruan atau praktek mengajar dalam lingkungan kecil atau terbatas (Khuriyah, 2017). Pada intinya, micro teaching adalaah sebuah sarana untuk pelatihan bagi mahasiswa calon guru dalam mengasah dan meningkatkan keterampilan dasar mengajar di dalam kelas micro teaching dengan jumlah lebih sedikit. Micro teaching bertujuan untuk memberikan kesempatan bagi mahasiswa calon guru untuk berlatih mempraktekkan keterampilan dasar mengajar didepan teman mahasiswa. Sehingga mempunyai kesiapan mental dalam tampil micro teaching di dalam kelas, keterampilan dasar mengajar yang diajarkan dosen micro teaching di dalam kelas,dan kemampuan mengajar untuk bekal pada praktek mengajar sesungguhnya disekolah (Khuriyah, 2017).

Persepsi merupakan pandangan seseorang terhadap orang lain (Junelti \& Syarif, 2020). Berdasarkan penelitian yang peneliti lakukan pada tanggal 10 dan 13 Juli 2020 di Jurusan Sosiologi, Fakultas Ilmu Sosial, Universitas Negeri Padang ada beberapa mahasiswa Pendidikan Sosiologi sebelum tampil micro teaching RPP dan media harus siap, ada yang gugup dalam kelas ada yang tidak gugup dalam kelas, ada yang belum siap untuk tampil dalam kelas micro teaching ada yang sudah siap untuk tampil di kelas micro teaching, ada yang tidak menguasai materi ada yang menguasai materi pembelajaran, tidak memberikan apersepsi ada yang memberikan apersepsi kepada siswa, mahasiswa calon guru memakai metode ceramah, diskusi, dan tanya

Jurnal Sikola: Jurnal Kajian Pendidikan dan Pembelajaran Vol. 2, No. 1, Th. 2020 
jawab, tidak terlalu menguasai kelas ada yang menguasai kelas, tidak memberikan motivasi kepada siswa dan ada juga memberikan motivasi kepada siswa, memberikan hadiah kepada siswa yang bisa menjawab pertanyaan dan membuat game supaya siswa semangat belajar.

Mengajar adalah menciptakan bentuk suasana yang memungkinkan terjadinya proses belajar (Nur Azizah, 2019). Para pendidik harus memperoleh bekal yang cukup agar dapat menguasai sejumlah kompetensi yang diinginkan (Untari, et al, 2018). Setelah dibekali ilmu yang di pelajari di micro teaching para mahasiswa calon guru mempraktekkan ilmu yang didapat di micro teaching ke praktek lapangan kependidikan disekolah. Mahasiswa mempraktekkan apa yang dipelajari di micro teaching, pada saat micro teaching diajarkan keterampilan dasar mengajar dan mengajarkan cara mengelola kelas dengan baik. Praktek lapangaan kependidikan dilaksanakan pada semester 7 dengan berbobot 4 SKS.

Mengajar adalah kegiatan yang sangat penting bagi seorang pendidik (Khuriyah, 2017). Belajar jadi pendidik merupakan suatu perjalanan sangat penting karena banyak pengelaaman, tantangan dan sukacita yang didapat. Tugas dan tanggung jawab pendidik sangatlah berat karena bukan tugasnya memberi pengetahuan, tetapi lebih dari itu harus membentuk pribadi murid secara utuh. Salah satu tugas pendidik yaitu mengajar, tugas yang sangat bermanfaat. Dikatakan berat karena tugas tersebut mempunyai tanggung jawab untuk membentuk kepribadian seseorang (Arifin, 2013). Dikatakan mulia karena ikut mencerdasakan anak bangsa menjadi berguna bagi nusa dan bangsa (Arifin, 2013).

Di dalam mengajar, pendidik harus mendorong peserta didik untuk memperoleh pengalaman dalam mengapresiasi dan kebersamaan (Arifin, 2013). Pendidik mempunyai kemampuan untuk memperkaya kehidupan peserta didik dengan cara mengajar yang terencana, kreatif, interaktif, dan inovatif. Guru juga mempunyai kemampuan untuk mengatasi frustasi peserta didik, membagi waktu dan pengalaman kepada peserta didik (Arifin, 2013). Pendidik harus siap melakukan pekerjaan dengan ikhlas, sehingga bisa menjadi pendidik yang profesional (Arifin, 2013). Untuk menjadi seorang pendidik yang berkemampuan dan peduli juga tidaklah gampang. Ia harus menguasai materi pembelajaran, membuat perencanaan pembelajaran yang baik, melakukan pembelajaran dengan kehangatan, melakukan penilaian cara mendidik (Arifin, 2013).

Berdasarkan penelitian yang peneliti lakukan pada tanggal 10 dan 13 Juli 2020 di Jurusan Sosiologi, Fakultas Ilmu Sosial, Universitas Negeri Padang ada beberapa mahasiswa Pendidikan Sosiologi sebelum masuk kelas, mahasiswa praktek lapangan kependidikan harus menyiapkan RPP dan media yang akan di tampilkan, ada mahasiswa yang gugup, cemas pada PLK ada juga yang tidak gugup, cemas pada PLK dan merasa takut diganggu sama siswa, ada menguasai materi dan ada juga tidak menguasai materi pembelajaran yang akan diajarkan kepada siswa, ada yang memberikan apersepsi dan ada juga tidak memberikan apersepsi kepada siswa, mahasiswa PLK memakai metode ceramah, diskusi dan tanya jawab dalam kelas, ada yang tidak menguasai kelas dan ada juga yang menguasai kelas, mahasiswa PLK memberikan motivasi kepada siswa dan ada juga yang tidak memberikan motivasi kepada siswa, memberikan hadiah kepada siswa yang bisa menjawab pertanyaan dan membuat game supaya siswa semangat belajar dalam kelas. Ada yang tidak memakai langkah-langkah micro teaching di sekolah karena siswanya tidak mau diatur di dalam kelas, untuk itu mahasiswa PLK mengambil inisiatif bagaimana pembelajaran tetap berlangsung dan lancar pada proses pembelajaran di kelas, ada yang memakai langkah-langkah micro teaching saat praktek lapangan kependidikan karena dengan memakai langkah-langkah micro teaching dapat membantu mahasiswa PLK dalam pembelajaran disekolah. Dengan mempelajari keterampilan dasar mengajar di micro teaching mahasiswa mendapat bekal untuk diterapkan dalam pelaksanaan praktek lapangan kependidikan di sekolah.

Teori yang dipakai dalam penelitian ini adalah struktural fungsional dari Talcott Parson (Upe, 2010). Aliran ini berasumsi dasar bahwa masyarakat merupakan suatu sistem yang terdiri dari bagian-bagian yang saling berkaitan dan berfungsi dengan bagian-bagian yang lainnya.

Jurnal Sikola: Jurnal Kajian Pendidikan dan Pembelajaran Vol. 2, No. 1, Th. 2020 
Apabila bagian tidak berfungsi dengan baik, maka akan mempengaruhi bagian sistem lainnya (Upe, 2010). Kelas micro teaching dan sekolah adalah suatu sistem yang terdiri dari berbagai subsub sistem dan memiliki fungsi yang saling berkaitan satu sama lain. Kelas micro teaching dan sekolah adalah institusi formal untuk menjadikan mahasiswa calon guru yang profesional dalam mengajar dan mendidik siswanya. Menurut Parson, ada empat fungsi penting pada teori struktural fungsionalisme yaitu Adaptation (adaptasi), Goal Attainment (Pencapaian Tujuan), Integration (Integrasi), Latency (pemeliharaan) (Ritzer \& Goodman, 2011).

Pada tahap awal mahasiswa calon guru melalui proses adaptasi dalam kelas micro teaching, pada micro teaching mahasiswa calon guru diajarkan keterampilan dasar mengajar di dalam kelas micro teaching dan dosen memberikan kesempatan kepada mahasiswa calon guru untuk tampil 2-3 kali supaya terbiasa untuk mengajar di kelas dan di lapangan. Tujuan micro teaching membekali tenaga pendidik beberapa keterampilan dasar mengajar dan pembelajaran. Pada tahap awal mahasiswa PLK melalui proses adaptasi disekolah dengan yang telah dipelajari selama micro teaching supaya tidak kaku dalam kelas. Tujuan praktek lapangan kependidikan adalah supaya terbiasa mahasiswa dalam memiliki kemampuan ilmu yang dipelajari dalam situasi nyata, baik untuk kegiatan mengajar maupun non mengajar.

Pada tahap integration (integrasi) suatu sistem mengatur hubungan dengan bagian dengan bagian yang lainnya. Pada micro teaching mahasiswa calon guru sudah selesai menjelaskan materi pembelajaran dan menutup pelajarannya, di akhir penampilan mahasiswa calon guru diberikan kritik dan saran dari dosen dan mahasiswa supaya penampilan selanjutnya lebih bagus. Pada praktek lapangan kependidikan kalau ada siswa yang malas belajar dan tidur dikelas, mahasiswa PLK menegur siswa tersebut dan memberikan motivasi supaya siswa tersebut semangat belajar.

\section{Kesimpulan}

Didalam mata kuliah micro teaching mahasiswa Pendidikan Sosiologi diajarkan keterampilan dasar mengajar, pada micro teaching mahasiswa diharapkan dapat menguasai keterampilan dasar mengajar dalam kelas supaya saat dalam praktek lapangan kependidikan tidak gerogi, cemas lagi dalam kelas. Tujuan micro teaching membekali tenaga pendidik beberapa keterampilan dasar mengajar dan pembelajaran. Setelah dibekali ilmu yang dipelajari di micro teaching mahasiswa calon guru mempraktekkan ilmu yang di dapat di micro teaching ke pelaksanaan praktek lapangan kependidikan. Tujuan praktek lapangan kependidikan adalah supaya terbiasa mahasiswa dalam memiliki kemampuan ilmu yang dipelajari dalam situasi nyata, baik untuk kegiatan mengajar maupun non mengajar. Mahasiswa mempraktekkan apa yang dipelajari di micro teaching. Penelitian ini mendapatkan hasil bahwa Mahasiswa Pendidikan Sosiologi ketika pelaksanaan praktek lapangan kependidikan memakai langkah-langkah micro teaching dan menguasai keterampilan dasar mengajar di kelas, dengan memakai langkah-langkah micro teaching dan menguasai keterampilan dasar mengajar yang diajarkan dosen membantu mahasiswa Pendidikan Sosiologi dalam pelaksanaan praktek lapangan kependidikan di sekolah.

\section{Daftar Pustaka}

Arifin, Z. (2013). Menjadi Guru Profesional (Isu dan Tantangan Masa Depan). Edutech, 13(1), $132-155$

Ardi, M. (2014). Pelaksanaan Pembelajaran Micro Teaching Bagi Mahasiswa Program Studi PPKn STKIP-PGRI Pontianak. Jurnal Edukasi, 1(88), 75-84.

Wati, D.D.E. (2017). Persepsi Guru Pamong Terhadap Profesional Mahasiswa Praktek Lapangan Kependidikan. Bioconcetta, 3(2), 9-21.

Ritzer \& Goodman, J. (2011). Teori Sosiologi Modern Edisi Ke 6. Jakarta: Kencana.

Ira, F., \& Syamwil, R. S. (2018). Persepsi Mahasiswa Tentang Efektivitas Program Pengalaman Lapangan Kependidikan (PPLK) Terhadap Kesiapan Menjadi Guru Pada Mahasiswa Pendidikan Ekonomi Unp. Jurnal EcoGen, 1(1), 955-966. 
Iyan Setiawan, S. M. (2018). Efektivitas Mata Kuliah Pembelajaran Mikro (MicroTeaching) Terhadap Keterampilan Dasar Mengajar Dan Kesiapan Mengajar. Jurnal Penelitian Pendidikan dan Ekonomi, 15(2), 51-60. https://doi.org/10.25134/equi.v15i02.Abstract

Junelti, A. D., \& Syarif, W. (2020). Persepsi Peserta Didik Kelas X11 Tata Boga Terhadap Mahasiswa Yang Melaksanakan PLK Di SMKN 2 Kota Pariaman. Jurnal Kapita Selekta Geografi, 3(1), 41-50

Khuriyah, K. (2017). Analisis Pelaksanaan Microteaching Mahasiswa Program Studi Pendidikan Agama Islam. At-Tarbawi: Jurnal Kajian Kependidikan Islam, 2(2), 175-194.

Mardalis. (2010). Metode Penelitian Suatu Pendekatan Proposa. Jakarta : Bumi Aksara.

Nana, S. (2013). Metode Penelitian Pendidikan. Bandung : PT Remaja Rosdakarya.

Nur Azizah, E. R. (2019). Persepsi Mahasiswa Tentang Peranan Mata Kuliah Micro Teaching Terhadap Kesiapan Mengajar pada Mahasiswa Pendidikan Ekonomi UNP. Jurnal EcoGen, 2, 197-205.

Satuik Rahayu, I. G. M. (2017). Pengembangan Bahan Ajar Micro Teaching untuk Melatih Kompetensi Pedagogik Calon Guru. Jurnal Pendidikan Fisika Dan Teknologi, 3, 232-238.

Sugiyono, S. (2017). Metode Penelitian Kuantitatif, Kualitatif. Bandung : Alfabeta.

Untari, T., Rahmaniah, R., Islami, A. B., \& Ihsani, B. Y. (2018). Peningkatan Pembelajaran Microteaching Melalui Pendekatan Kolaboratif. Jurnal Prakarsa Pacdagogia, 1(1), 91-100. http://jurnal.umk.ac.id/index.php/JKP

Upe, A. (2010). Tradisi Aliean dalam Sosiologi Dari Filosofi Positivistik kr Post Positivistik. Jakarta : Rajawali Perss.

Vadelha, R., \& Body, R. (2019). Sikap Percaya Diri Mealaksanakan Praktik Lapangan Kependidikan Podi PTB FT-UNP. Jurnal Cived, 6(1), $2-7$.

Yusuf, A. M. (2007). Metode Penelitian Dasar-Dasar Penyelidikan Ilmiah. Padang : UNP Press. 